\title{
IMPACTS OF COVID-19 ON TOURISM EMPLOYMENT
}

\author{
[Dopady covid-19 na zaměstnanost v cestovním ruchu] \\ Milena Botlíková ${ }^{1}$, Josef Botlík ${ }^{2}$ \\ ${ }^{1}$ Slezská univerzita v Opavě, Filozoficko-přirodovědecká fakulta, Masarykova 343/37,746 01 Opava \\ Email:milena.botlikova@fpf.slu.cz. \\ ${ }^{2}$ Slezská univerzita v Opavě, Obchodně podnikatelská fakulta, Univerzitní nám. 1934/3, 73340 Karviná \\ Email:botlik@opf.slu.cz
}

\begin{abstract}
Tourism is based primarily on tourist flows. The current Covid-19 pandemic, which brings isolation and closure of regions, is an obstacle to its development. According to the professional public, the most affected sector is tourism. The decline in tourism represents a loss for companies, state budget revenues, and an employment decline. Governments' efforts to eliminate redundancies through various support packages have not stopped the increase in redundancies. A more extended period of restraint leads to a rise in unemployment; if the economy does not relax, unemployment growth in the tourism sector can be expected to accelerate.
\end{abstract}

Keywords: Covid-19, EU, region, tourism, unemployment.

JEL classification: E24, L83

Received: 28.6.2021; Reviewed: 29.7.2021; 23.8.2021; Accepted: 3.11.2021

\section{Úvod}

Pandemie covid-19 výrazně zasáhla hospodářský, politický i společenský život v globálním prostoru. Z historie je známo, že cestovní ruch je velmi citlivý vůči různým bezpečnostním rizikům, at' se jednalo o pandemii v roce 2002 (SARS-CoV) nebo teroristické útoky, např. ve Francii či Bruselu v roce 2016 (Pellešová 2016), ty však neměly na fungování cestovního ruchu tak rozsáhlé negativní důsledky. Současná pandemie představuje největší zásah do cestovního ruchu od roku 1950 a představuje náhlý konec desetiletého období udržitelného růstu (Kitamura a kol. 2020).

S rozšiřováním pandemie docházelo k mnoha restrikcím, např. zákazu přeshraničního pohybu, izolování skupin obyvatelstva atd. Jelikož je cestovní ruch založen především na tocích turistů, představuje covid-19 a restrikce $\mathrm{s}$ ním spojené značnou bariéru jeho rozvoje. Podobně jako v České republice, také v jiných zemích, cestovní ruch zaznamenal totální úpadek, uzavřely se hotely, restaurační zařízení, muzea, letecké společnosti zůstaly „na zemi“. Pro období 2020 se odhadoval $78 \%$ pokles globálního př́ijezdového cestovního ruchu a ztráta 20 milionů př́mých pracovních míst v cestovním ruchu, což bylo třikrát více než po útoku 11 . záŕí 2001 (Sigala 2020). Globálně je turismus považován, za nejvíce postižené hospodářské odvětví covidem-19; v souvislostech s turismem nejde jen o dopady na cestovní ruch, $\mathrm{z}$ podstaty multidimenzionální provázanosti cestovního ruchu jsou dopady daleko širší, jde o postižení v oblastech letectví, stravovacích službách, pozemní dopravě, umění nebo kultuře (KPMG 2020). Pravděpodobně nejzranitelnější destinace byly země s dominantním zahraničním cestovním ruchem. Dopady na cestovní ruch však představují nejen absenci toků turistů samotných. Došlo rovněž k výpadkům na devizových účtech regionů, příjmů ve formě $\mathrm{DPH}$, daní $\mathrm{z}$ prŕíjmů, poklesu investic a $\mathrm{v}$ neposlední řadě $\mathrm{k}$ nárůstu nezaměstnanosti $\mathrm{v}$ cestovním ruchu. 


\section{Dopady pandemie na zaměstnanost $\mathbf{v}$ cestovním ruchu}

Problematikou dopadu se zabývala řada autorů. V mnoha zemích je zaměstnanost závislá právě na cestovním ruchu. Pracovní trh představuje jistou strukturu pracovního postavení (Remeikis 2020), cestovní ruch absorbuje značné procento subdodávek, OSVČ, pracovních dohod, př́iležitostných zaměstnanců, popř́ípadě výpomocí rodinných příslušníků. Právě tito zaměstnanci nemají během pandemie př́stup k různým opatřením ze strany vlád a jsou daleko zranitelnější. Přestože byla vytvořena různá podpůrná opatření zaměstnanosti (daňové úlevy, dotace, vouchery, ...), je zřejmé, že dochází ke snižování zaměstnanosti v turismu. Bauma a Nguyena (2020) predikovali s prodlužováním doby pandemie výraznější pokles nezaměstnanosti než na počátku pandemie. Dá se předpokládat, že čím bude pandemie delší, dopady na cestovním ruchu budou daleko dramatičtější. Vazby zaměstnanosti a pandemie zkoumali Vaisharand a Št’astná, (2020); konstatují, že pokles cestovního ruchu v České republice tlumí nárůst venkovského cestovního ruchu, který zároveň tlumí růst nezaměstnanosti. Dále konstatují, že podzimní vlna (2020) pandemie by mohla přinést ztráty domácímu cestovnímu ruchu České republiky v důsledku sníženého zájmu o firemní akce a školení. K prohlubování nezaměstnanosti v cestovním ruchu vede menší ochota $\mathrm{k}$ poptávce $\mathrm{v}$ důsledku ekonomických nejistot, ztráty př́ijmu, obav z případné kontaminace virem nebo jen uvědomění si závažnosti (Vaishar, Št’astná 2020).

Pro hodnocení dopadů covid-19 využívá Kitamura a kol (2020) hodnocení MICE a spotřeby domácího a př́jezdového cestovního ruchu. Vývojem cestovního ruchu v době covidu se zabývá také Šenková (2021), která pro hodnocení vývoje využívá hodnocení kapacit hromadných ubytovacích zařízení cestovního ruchu a jejich tempa růstu.

\section{Metody a data}

Cílem článku je analyzovat a kategorizovat evropské regiony podle míry změn zaměstnanosti a toků turistů v době pandemie covid-19 na základě deskripce a komparace. Pro hodnocení dopadů pandemie na cestovní ruch bylo využito ukazatelů vývoje zaměstnanosti v ubytovacích a stravovacích zařízeních, celkem, a také samostatně. Dále byl vývoj komparován s vývojem cestovního ruchu. Ukazatelem vývoje bylo srovnání počtu turistů ubytovaných $\mathrm{v}$ hromadných ubytovacích zařízeních jednu a více nocí. $Z$ důvodu absence dat bylo vyloučeno Německo z analýzy zaměstnanosti, hodnocení tak vycházelo z EU-26. $\mathrm{Z}$ podobného důvodu byly vyloučeny $\mathrm{z}$ komparace zaměstnanosti a návštěvnosti destinace Francie, Irsko a Bulharsko, Řecko. Výsledkem bude zařazení regionů do skupin souhrnného pořadí vybraných kritérií, která jsou kritérií minimalizačními. Znamená to, že nejvhodnější meziroční změna je minimální hodnota daného kritéria. Hodnota meziroční/mezikvártální změny byla vypočtena jako míra růstu $\mathrm{v}$ procentech $(\%)$. Jednotlivá data vycházela $\mathrm{z}$ databáze EUROSTAT a webových informací. Analýza vývoje vychází z komparace období Qi/2019 a Qi/2020 (Qi = kvartál, i=1,2,3,4).

V př́padě, analýz dopadu covidu na segmenty bylo použito rozdělení podle vývoje změn zaměstnanosti v podnicích gastronomických a hotelových mezi kvartály Qi/2020-2019. V případě, že po celé období byly meziroční změny (2Q až 4Q/2020-2019) vyšší poklesy $\mathrm{v}$ hotelovém segmentu pak byly regiony označeny světle šedou barvou. V případě, že region vykazoval ve dvou obdobích ze tř́ vyšší poklesy na trhu práce hotelových služeb, byl označen tento region barvou tmavě šedou. Analogicky pak v případě, že byla změna jen jedna ze tří, je zřejmé, že v regionu převažoval vyšší dopad na zaměstnanost v restauračních podnicích (nejsvětlejší šedá) a v př́ípadě, že podnik dosahoval vyšší změny/poklesy zaměstnanosti v restauračních podnicích po celé sledované období pak byl označen region nejtmavší šedou barvou. 


\section{Analýza vývoje zaměstnanosti ve vybraných zemích EU}

Vývoj zaměstnanosti v hotelových a stravovacích službách od roku 2016 vykazoval postupný nárůst. Tento trend by pravděpodobně pokračoval, pandemie jej zastavila. Celkově v EU-26 přišlo o práci v roce 2020 oproti roku 2019 cca 3801 tisíc pracujících v hotelnictví a restauracích, z toho 1138 tisíc v hotelových zařízeních. Průměrná mezikvartální změna zaměstnanosti let 2020-2019 v evropských hotelech a restauracích se pohybovala v období Q2-Q4/2020-2019 na úrovni mínus 16,1\%, medián změn byl obdobný: -16,1\%. Po nástupu pandemie $(\Delta \mathrm{Q} 2 / 2020-2019)$ se nejnižší pokles zaměstnanosti projevil v Lotyšsku (pokles o $0,3 \%$ ), další čtvrtletí se situace zhoršila a Lotyšsko se umístilo mezi nejpostiženějšími regiony $(\Delta$ o $-26,3 \%)$. Mezi regiony s dobrou situací patřila Malta (pokles o 3,5\%), situace se během roku zhoršila (viz obrázek 1). Za nízkým poklesem stál nárůst klientů cestovního ruchu o $5,8 \%$. Další destinaci s nejmenšími dopady pandemie na zaměstnanost byla Francie (pokles o 4,3\% 2Q/2020-2019), ta patřila během jednotlivých čtvrtletí roku 2020 oproti roku 2019 mezi méně postižené. Nejvyšší pokles zaměstnanosti v cestovním ruchu zaznamenalo Bulharsko (pokles o 34,5\%), Irsko (pokles o 29,6\%) a Finsko (pokles o 29,4\%). Nejpostiženějším regionem v Q2/2020 a Q3/2020 je Kypr $(\Delta \mathrm{Q} 2 / 2020-2019$ o $-31,7 \%$; Q3/2020-2019 o $35,4 \%$ ). Luxemburg byl jedinou destinací, která zaznamenala v roce 2020 nárůst (nárůst Q4/2020-2019 o 24,2\%, viz obrázek 1).

Obrázek 1: Qi změny zaměstnanosti v segmentech cestovního ruchu zemí EU

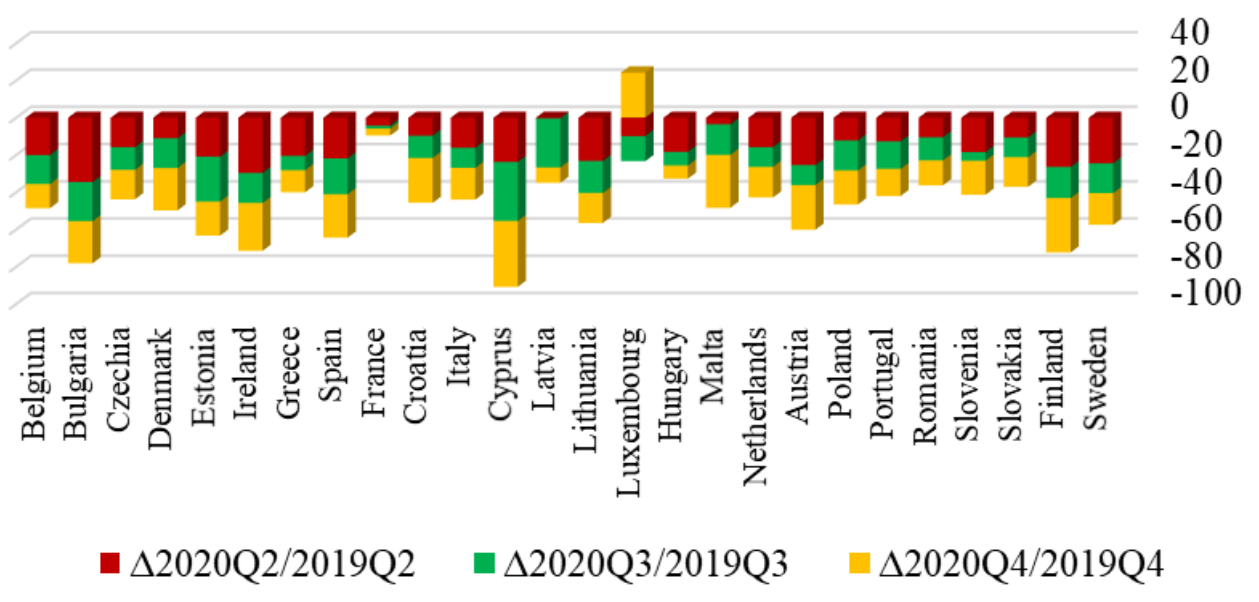

Zdroj: Webový portál Eurostat: Employees by sex, age and economic activity [online] [vid. 15. dubna 2021]. Dostupné z https://appsso.eurostat.ec.europa.eu/nui/submitViewTableAction.do

V EU-27 pandemie zasáhla především zaměstnanost v hotelových službách, největší úroveň změn míry zaměstnanosti (pokles) oproti předešlému období se v zaměstnanosti EU-27 projevila v období Q4/2020-2019, což vypovídá o prohlubující se krizi a také ukazuje dopady druhé vlny pandemie covid-19. Podle obrázku č. 2 je zřejmé, že během analyzovaného období převažují země, kde pandemie více zasáhla zaměstnanost $\mathrm{v}$ restauračních podnicích (světle modře a modře označené.). Naopak u zeleně a oranžově označených zemí byly zaznamenány vyšší poklesy zaměstnanosti v segmentu hotelových služeb. Pokud budeme hodnotit vývoj změn mezi jednotlivými kvartály roku 2020, pak 23,08\% (6) regionů mělo během období vždy vyšší pokles zaměstnanosti v hotelových službách než v restauračních podnicích po celé období a shodně 23,08\% (6 regionů) zaznamenalo převažující dopady v hotelových službách. Ve 26 regionech Evropské unie převažovaly regiony (38,46\%), kde se projevoval pokles zaměstnanosti převážně v podnicích restauračního typu. Ve 4 regionech $(15,38 \%$; Česko, Lotyšsko, Rumunsko a Slovinsko) docházelo po celý rok 2020 k vyšším poklesům zaměstnanosti v restauračních podnicích oproti hotelovým. 
Obrázek 2: Skupiny regionu podle převažujících dopadů pandemie na zaměstnanosti v Q2Q4/2020-2019
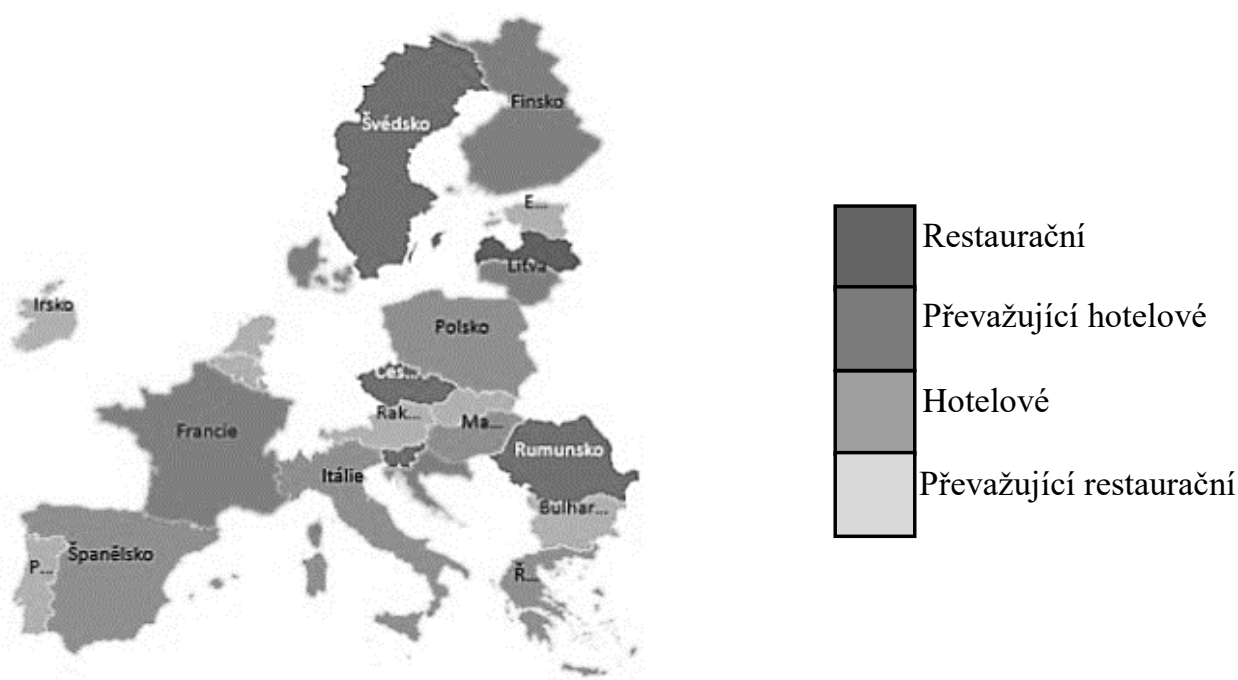

Zdroj: Webový portál Eurostat: Employees by sex, age and economic activity [online] [vid. 15. dubna 2021]. Dostupné z https://appsso.eurostat.ec.europa.eu/nui/submitViewTableAction.do

Po celou dobu (Qi/2020-2019) docházelo, s výjimkou Francie a Lucemburska, k poklesu zaměstnanosti ve stravovacích službách. Jak je patrné, celkové dobré pozice během krize dosáhlo Lucembursko, které ve Q2 a Q4 zaznamenalo nárůst zaměstnanosti v hotelových službách.

Obrázek 3: $Q_{i}$ změny zaměstnanosti v hotelových a restauračních služeb zemí EU
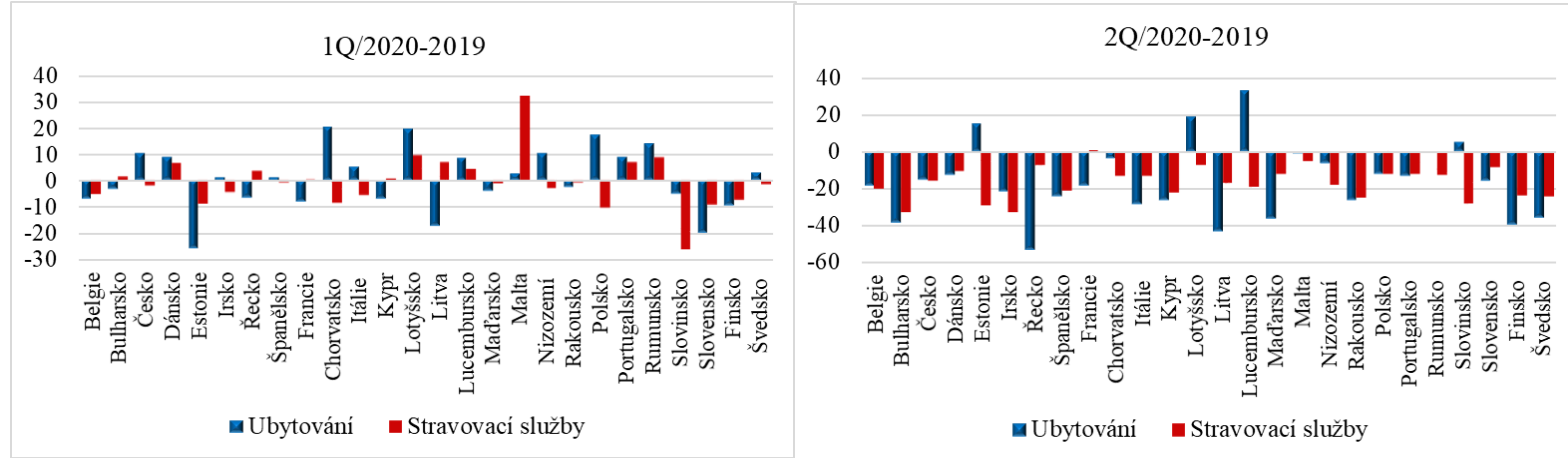

$3 \mathrm{Q} / 2020-2019$
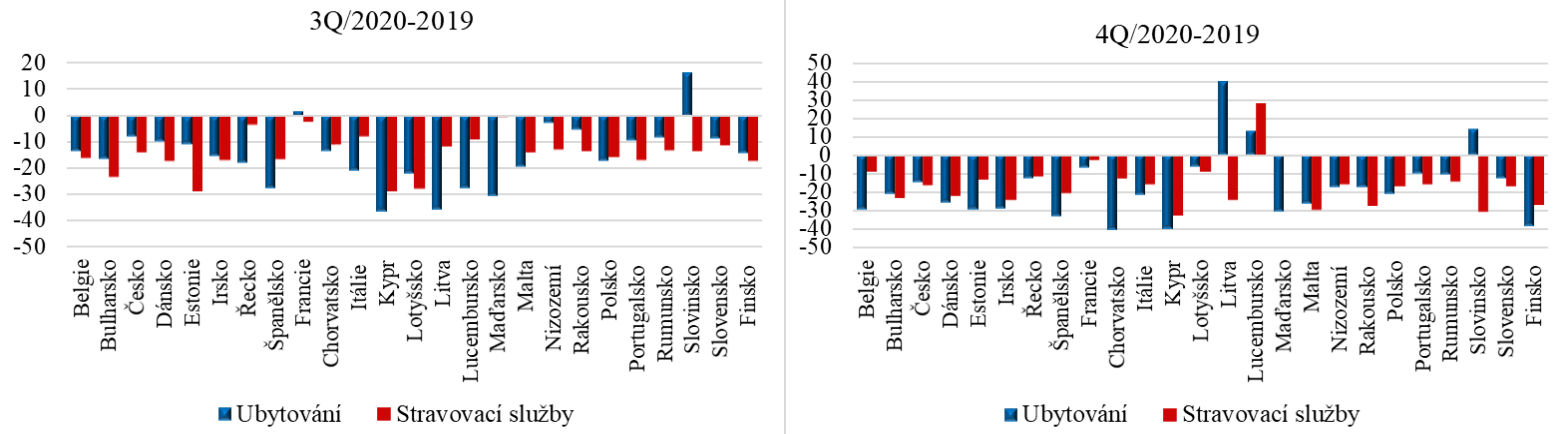

Zdroj: Webový portál Eurostat: Employees by sex, age and economic activity [online] [vid. 15. dubna 2021]. Dostupné z https://appsso.eurostat.ec.europa.eu/nui/submitViewTableAction.do

Mírný nárůst počtu zaměstnanců hotelových služeb v počátku pandemie se projevil ve Slovinsku, Estonsku a Litvě. V kvartálech Q3 a Q4 si udržela z těchto tří destinací růst zaměstnanosti pouze destinace Slovinsko, Litva pouze ve čtvrtém kvartálu. Francie si po 
celou dobu udržela nízké mezikvartální změny jak u ubytování, tak u stravovacích služeb, prvotní vysoký pokles zaměstnanosti (o 4,3\%) ve Q2/2020-2019 tlumil mezikvartální nárůst ve stravovacích službách (růst o 2,9\%), ve Q3/2020-2019 pak tlumily pokles ubytovací služby (růst o $1,5 \%$, blíže obrázek 3 . Vyšší propady nezaměstnanosti ve stravovacích službách lze přisoudit zastoupení malých podniků v tomto segmentu. Oproti hotelovým podnikům, které jsou převážně zastoupeny středními nebo velkými, mnohdy nadnárodními společnostmi, tvoří velké procento restaurací malé, rodinné firmy. Velké podniky jsou tak více odolné vůči krizím, jejich kapitálová struktura umožňuje podobným hrozbám lépe vzdorovat.

\section{Seskupení regionů podle vývoje zaměstnanosti ve vybraných zemích $\mathbf{E U}$}

Dopady pandemie v podstatě způsobily v mnoha zemích EU zastavení činnosti ubytovacích zařízení. Podle obrázku 4 zaznamenal nejmarkantnější pokles hostů v HUZ v Q2/2020 oproti období 2019 region Malta, který rovněž zaznamenal nejnižší propad zaměstnanosti oproti minulému období. Severské země, u kterých se neprojevovaly nejdramatičtější poklesy návštěvnosti hromadných zařízení, měly vyšší poklesy zaměstnanosti ve vybraném segmentu cestovního ruchu. Z grafu Q3/2020-2019 (obrázek 4) je zřejmé, že se cestovní ruch pomalu rozvíjel, nicméně podzimní vlna pandemie vedla opět k propadům. V Q2/2020-2019 došlo k vysokým meziročnímu poklesům v návštěvnosti, ale nepatrnému poklesu zaměstnaností v Lotyšsku, Chorvatsku a Maltě. Ve Q3/2020-2019 se projevil podobný vývoj v Mad'arsku, ve Q4/2020-2019 opět v Mad'arsku a Lotyšsku. Naopak na Kypru se v období Q3 a Q4 projevoval velký pokles zaměstnanosti oproti minulému období, který doprovázel nižší poklesy návštěvnosti. V rámci sledovaného období bylo zřetelné, že na Maltě postupné prodlužování pandemie vedlo ke zvyšování nezaměstnanosti. Jedinou zemí, která vykazovala pozitivní vývoj meziročních změn během období, bylo Lucembursko.

Obrázek 4: Vztah mezi změnami zaměstnanosti a změnami počtů turistů v HUZ ve vybraných zemích EU

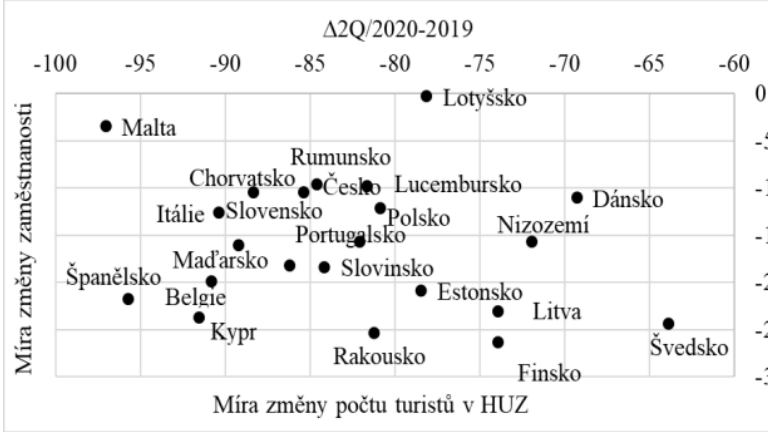

$\triangle Q 4 / 2020-2019$
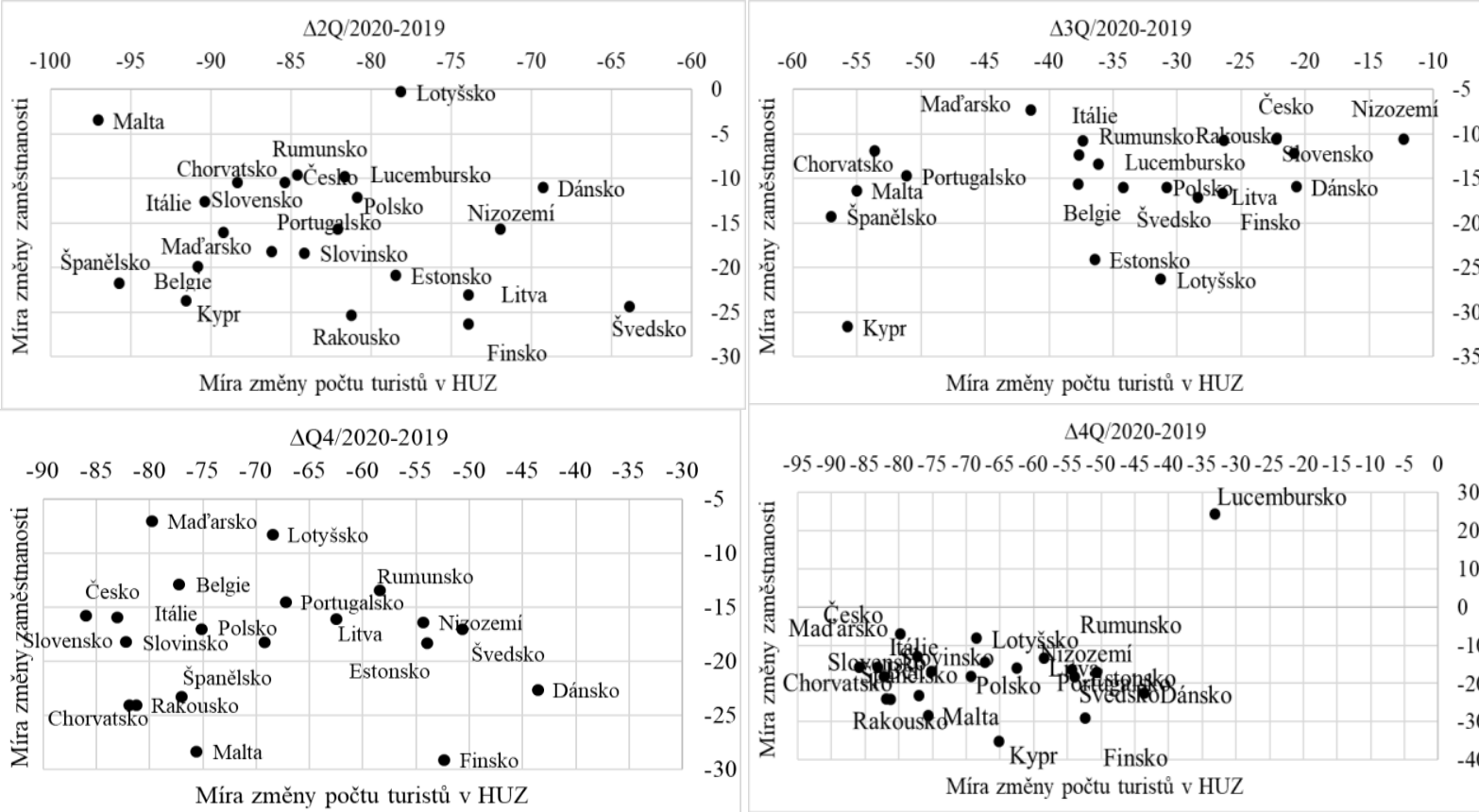

$\triangle 4 Q / 2020-2019$
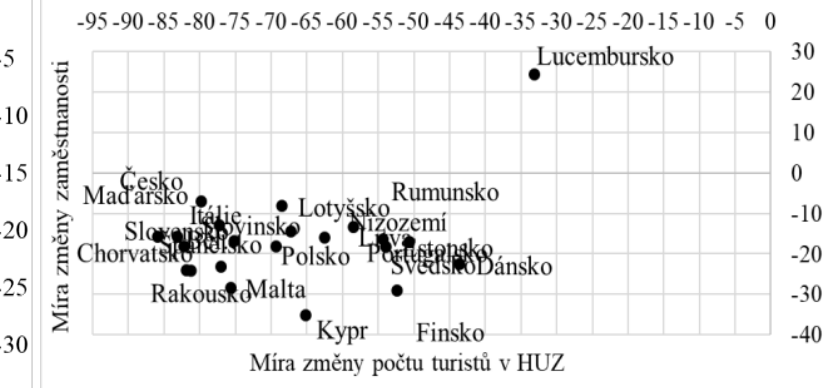

Zdroj: Webový portál Eurostat: Employees by sex, age and economic activity [online] [vid. 15. dubna 2021]. Dostupné z https://appsso.eurostat.ec.europa.eu/nui/submitViewTableAction.do

Na obrázku 5 jsou vybrané regiony seřazeny podle souhrnného pořadí mezi-kvartálních změn zaměstnanosti a tokové veličiny cestovního ruchu shrnuty do čtyř kvadrantů $A, B, C$ a D (viz 
tabulka 1). Souhrnné pořadí bylo konstruováno jako průměrná hodnota pořadí ukazatelů míry změn za období Q $\mathrm{Q}_{\mathrm{i}} / 2020-2019$. Čím vyšší hodnota pořadí, tím byly regiony více postiženy negativním vývojem zaměstnanosti nebo negativním vývojem turistického ruchu.

Tabulka 1: Souhrnné umístění regionu podle pořadí míry změn ukazatelů $\mathrm{Q}_{\mathrm{i}} / 2020-2019$

\begin{tabular}{|c|c|c|c|}
\hline & & \multicolumn{2}{|c|}{ Míra změny návštěvnost $\mathrm{Q}_{\mathrm{i}} / 2020-2019}$. \\
\hline & & Nízké & Vysoké \\
\hline \multirow{2}{*}{$\begin{array}{c}\text { Míra změny zaměstnanosti } \\
\mathrm{Q}_{\mathrm{i}} / 2020-2019\end{array}$} & Nízké & $\mathrm{A}$ & $\mathrm{D}$ \\
\cline { 2 - 4 } & Vysoké & $\mathrm{B}$ & $\mathrm{C}$ \\
\hline
\end{tabular}

Zdroj: Vlastní zpracování

Jak je vidět, nejpostiženější regiony za období 2020 jsou ty, jež jsou závislé na cestovním ruchu, tj. Španělsko, Kypr, které zaznamenaly vysoký výpadek cestovního ruchu, především zahraničního. Nicméně je zřejmé, že s problémem vysokého poklesu zaměstnanců v hotelových a stravovacích službách se setkaly i regiony s nižším poklesem cestovního ruchu, vyjádřeným počtem turistů v hromadných ubytovacích zařízeních. Př́znivější vývoj zaměstnanosti proběhl Lucembursku, dále také v Nizozemí, ale i České republice.

Obrázek 5: Rozdělení regionů podle pořadí jednotlivých skupin

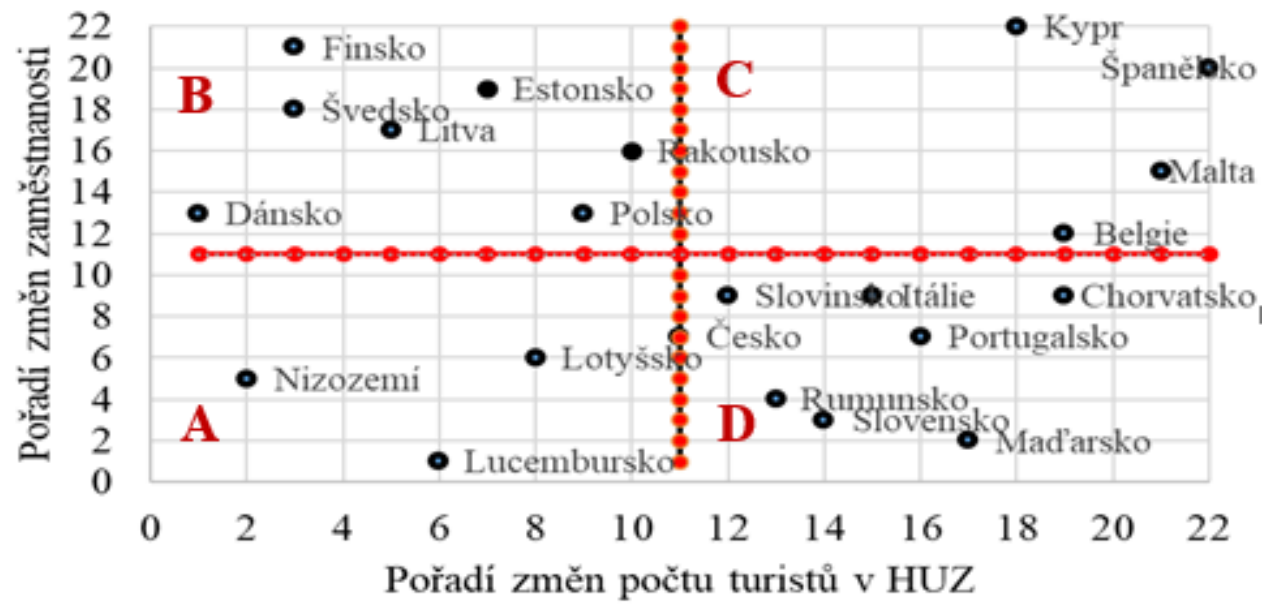

Poznámka: Vlastni zpracování, červené čáry představuji průměrné umistění (hodnota $x, y=11$ ).

Zdroj: Webový Zdroj: portál Eurostat: Arrivals at tourist accommodation establishments - monthly data online] [vid. 15. dubna 2021]. Dostupné z: https://appsso.eurostat.ec.europa.eu/nui/show.do?dataset=tour_occ_arm\&lan $\mathrm{g}=\mathrm{en}, \mathrm{Webový}$ portál Eurostat: Employees by sex, age and economic activity [online] [vid. 15. dubna 2021]. Dostupné z https://appsso.eurostat.ec.europa.eu/nui/submitViewTableAction.do

\section{Závěr}

$\mathrm{Z}$ výsledku vyplynulo, že byl více postižen hotelový sektor oproti restauračnímu. Restaurace flexibilně, pravděpodobně i z povahy uspořádání, reagovaly na možnost objednávkového systému přes ulici. Mezi vývojem změn turistů a změn zaměstnanosti neexistuje lineární korelace, může tedy mezi nimi existovat jiný než lineární vztah. Nicméně zde je možné konstatovat, že vývoj zaměstnanosti není ovlivněn vývojem poptávky po ubytování a stravovacích službách, ale vývojem pandemie a politickými rozhodnutími států. Nejpříznivější vývoj zaměstnanosti se projevil v Lucembursku, nepříznivá situace se jeví v regionech závislých na cestovním ruchu. Nepř́znivá situace je také v Rakousku. Problémem rakouského trhu práce $\mathrm{v}$ odvětví cestovního ruchu je, že v rakouském ubytování a gastronomii je vysoký podíl zahraničních pracovních sil, dokonce převyšuje domácí (Business 2020). Výhodná pozice Nizozemí může být dána otevřeností regionu i v době pandemie. Nizozemí provedlo tzv. „Intelligent lockdown“: „...neuzavřelo svoje hranice se sousedními státy, 
obyvateli̊m je ale doporučeno zatím necestovat. Po př́letu/př́ijezdu do země není povinná karanténa ..."(Business 2020).

Značný problém $\mathrm{v}$ boji proti pandemii vychází z jejího charakteru, neviditelná povaha předurčuje náročnější a zdlouhavější zvládání této krize. Je rovněž nutné „...přehodnotit dlouhodobou životaschopnost existujících forem práce $\mathrm{v}$ cestovním ruchu $\mathrm{a}$ pohostinstvi“" (Plastow 2020). Bude nutné reflektovat trend flexibilnosti pracovních sil, která umožní plynulý přechod do odvětví, tak jak se stalo za současné pandemie, kdy narůstající nezaměstnanost $\mathrm{v}$ ekonomikách byla tlumena nárůstem poptávky po zaměstnancích ze strany obchodních společností, call center atd. (Martins a kol. 2020). Prozatím je rozjezd cestovního ruchu velmi pomalý a je možné, že podle zprávy WYSE z roku 2020, kde se uvádí, že: „,celosvětová podnikatelská komunita je pesimistická, většina respondentů očekávala, že oživeni jejich podnikání začne v první polovině roku 2021, existovala však velká skupina, která neočekává, že se věci zlepši až do roku 2022 (12\%) nebo dokud nebude k dispozici vakcína (13\%)“ je, jak se ukázalo, reálný poslední scénář. Předpokládá se, že v budoucnu budou pandemie běžnější záležitostí (World Economic Forum 2019) a bude nutné je začlenit do strategií regionů, podnikatelských subjektů a každodenního života.

\section{Poděkování}

Článek byl vytvořen v rámci Institucionálního výzkumu MŠMT na Filosofickoprŕrodovědecké fakultě v Opavě, Slezské univerzity v Opavě.

\section{Literatura}

[1] BAUM, T. and TTN. HAI, 2020. Hospitality, Tourism, Human Rights and the impact of COVID-19. International Journal of Contemporary Hospitality Management, 32(7), 2397-2407. ISSN 0959-6119.

[2] BUSINESS, (2020). Nezaměstnanost v Rakousku: firmy využívají „kurzarbeit“.[online]. 10. 5. 2020 [vid. 12. dubna 2021]. https://www.businessinfo.cz/clanky/nezamestnanostv-rakousku-firmy-vyuzivaji-kurzarbeit/.

[3] EUROSTAT, (2021). Arrivals at tourist accommodation establishments - monthly data. [online]. 2021 [vid. 12. března 2021]. Dostupné Z: https://ec.europa.eu/eurostat/web/tourism/overview.

[4] EUROSTAT, (2021). Employees by sex, age and economic activity [online] 2021 [vid. 15. dubna 2021]. Dostupné z: https://appsso.eurostat.ec.europa.eu/nui/show.do?dataset=t our_occ_arm\&lang=en,

[5] HIGGINS-DESBIOLLES, F., 2020. Socialising tourism for social and ecological justice after COVID-19. Tourism Geographies, 22(3), 610-623. ISSN 1461-6688.

[6] KITAMURA, Y., S. KARKOUR, Y. ICHISUGI and Y. ITSUBO, 2020. Evaluation of the Economic, Environmental, and Social Impacts of the COVID-19 Pandemic on the Japanese Tourism Industry. Sustainability, 12(4), Article no. 10302. ISSN 2071-1050.

[7] KPMG, 2020. Government and institution measures in response to COVID-19. [online]. 2020 [vid. 12. března 2021]. Dostupné z: https://home.kpmg/xx/en/home/insights/2020/04/singapore-government-and-institutionmeasures-in-response-to-covid.html.

[8] MARTINS, A., T. RIORDAN and S. DOLNICA, 2020. A post-COVID-19 model of tourism and hospitality workforce resilience. SocArXiv [online]. 8 May 2020. 2020 [vid. 8. května 2021]. Dostupné z: https://osf.io/preprints/socarxiv/4quga/. 
[9] PELLEŠOVA, P., 2016. Descreption of Safety in terms of Tourism. In 16th International Scientific Conference on Globalization and its Socio-Economic Consequences, Žilina: Faculta Operation and Economics and Transport, Univerzita Žilina, Localization: Rajecké Teplice, Slovakia Date: 05-06 October 2016, 1665-1672. ISBN 978-80-8154191-9.

[10] PLASTOW, K., 2020. Wouldn't be able to pay rent': How coronavirus hurts casual workers. [online]. 2020 [vid. 12. května 2021]. Dostupné z: https://thenewdaily.com.au/finance/finance-news/2020/03/11/coronavirus-casual-workerrent/

[11] SIGALA, M., 2020. Tourism and COVID-19: Impacts and implications for advancing and resetting industry and research. Journal of Business Research, 117, $312-321$. ISSN 0148-2963

[12] REMEIKIS, A., (2020). Australian government won't "jump to a solution" to help casual workers in coronavirus crisis. The Guardian website [online]. 10. March 2020 [vid. 22. února 2021]. Dostupné z: https://www.theguardian.com/world/2020/mar/10/australiangovernment-warned-not-to-drag-its-feet-on-help-for-casual-workers-in-coronavirus-cris

[13] VAISHAR, A. and M. ŠŤASTNÁ, 2020. Impact of the COVID-19 pandemic on rural tourism in Czechia Preliminary considerations. Current Issues in Tourism, 23, Article no. 1479. ISSN 1368-3500.

[14] VANÍČEK, J., A. ŠENKOVÁ and L. JAROLÍMKOVÁ, (2021). Tourism and the COVID-19 Global Pandemic - Analysis of Opinions of Czech and Slovak Tourism Students. In SHS Web of Conferences, 20th International Scientific Conference on Globalization and its Socio-Economic Consequences, Žilina: Faculta Operation and Economics and Transport, Univerzita Žilina, Location: Univerzita Žilina, Date: 21. -22November 2020, Article no. 01054. ISSN 2416-5182

[15] WYSE TRAVEL, When and where will recovery begin? [online]. 2020 [vid. 12. března 2021]. Dostupné z: https://www.wysetc.org/2020/08/when-and-where-will-recoverybegin/ 